\title{
IDENTIFYING TRIBUTARIES TO JACKSON LAKE IMPORTANT FOR SNAKE RIVER CUTTHROAT TROUT RECRUITMENT
}

\author{
SCOTT A. CARLETON $\downarrow$ U.S. GEOLOGICAL SURVEY \\ NEW MEXICO COOPERATIVE FISH AND WILDLIFE RESEARCH UNIT \\ NEW MEXICO STATE UNIVERSITY $\uparrow$ LAS CRUCES
}

\section{$\uparrow \quad$ ABSTRACT}

Across their range, native salmonid species are imperiled due to habitat loss, alteration, and competition with non-native salmonids. New challenges, such as the effects of climate change on stream flow and water temperature create new problems for these species and highlight the importance of understanding their juvenile and adult life histories. Specifically, identifying life history movement patterns as it relates to spawning sites and juvenile rearing streams. We measured strontium isotope values of 13 tributaries and mainstem waters of the lower Snake River and Jackson Lake as well as otoliths collected from resident/juvenile cutthroat trout to determine if we could find unique isotopic signatures throughout the watershed. Strontium isotope values were similar for otoliths and water samples collected at the same location. Strontium isotope yielded unique isotope values across the watershed and between tributaries and the Snake River and Jackson Lake. Only three tributaries were undifferentiated using strontium stable isotopes. These were Pilgrim, Dime, and Sheffield Creeks. Due to their close proximity geographically and their geologic similarities it is not surprising we were unable to differentiate these three tributaries from each other. Future work using trace element analysis might provide further differentiation between these three creeks. Using this new information, we can now begin to look at adult cutthroat from Jackson Lake and the Snake River and determine their natal origins and fidelity to spawning tributaries. Using this information, managers can guide conservation efforts for cutthroat trout in the Jackson Lake watershed.

\section{$\uparrow \quad$ INTRODUCTION}

Across their native ranges, cutthroat trout populations are imperiled due to habitat loss, habitat alteration, and introduction of non-native species (Liknes and Graham 1988, Behnke 1992, Hitt et al. 2003). These changes have not gone undetected and a great deal of time and money has been invested in conservation and restoration of cutthroat trout populations (Kershner 1995, USDA 1996, Young and Harig 2002, Baker et al. 2008). The success of these projects is tightly linked to the ability of resource managers to prioritize management efforts. Specifically, where to focus the investments of time and money that will result in the greatest impact on conservation and restoration efforts. This study proposes to use a relatively new, proven analytical tool, stable isotope analysis, that will be used to identify differences in the stable isotope signatures of tributary streams entering Jackson Lake. These differences are translated into the tissues, specifically otolith bones, of cutthroat trout that use these tributaries during early life stages or upon return for spawning (Muhlfeld et al. 2005, Coghlan et al. 2007, Barnett-Johnson et al. 2008, Walther et al. 2008, Ziegler and Whitledge 2010). The ability to link adult trout back to their natal origins and identify where these adults are returning to spawn will provide the data resource managers need to prioritize conservation and restoration efforts in the upper Snake River watershed; with special emphasis on tributary streams entering Jackson Lake. 


\section{Why are stable isotopes so useful in expoloring this conservation need?}

Within a watershed, bedrock geomorphology can exhibit a high degree of heterogeneity. This is especially evident in the Rocky Mountains of the western United States, specifically in and around the Greater Teton and Yellowstone National Parks. Geologic heterogeniety of watersheds is the key to understanding the power of isotopic analysis in reconstructing the life histories of fish. Different geologic substrates (granite, sandstones, limestones, etc.) often contain different proportions of elements. Most elements have different forms, called isotopes, and the ratio of these isotope forms changes between rock types and with the age of the rock (Barnett-Johnson et al. 2008). Different rock types have variable, yet predictable, abundances of the isotopes of different elements. For example, the element strontium has two stable isotope forms; strontium 86 and strontium 87. As rocks form, they incorporate different amounts of the strontium isotopes. Additionally, as rocks age, radioactive ribidium $(\mathrm{Rb})$ decays to strontium 87 thus altering the abundance of this isotope in the rock. Using new analytical techniques, we can measure these differences and quantify the ratio of the heavier (87) to the lighter (86) isotope of strontium. This is important, because when streams and rivers arise from different geologic substrates within a watershed, they often yield significantly different strontium isotope signatures.

We can indirectly measure the strontium isotope signature of the geologic substrates in a watershed. As water passes over rock or percolates through the ground it slowly erodes the rock and becomes a direct, elemental and isotopic, reflection of the rock type(s) it has passed over and through. Fish absorb the strontium isotope signature of the water directly into their tissues. Fish then become a direct reflection of the water they live in which is a direct reflection of the geology the water has passed over and through.

One particular tissue in fish that records this environmental signature is an ear bone called an otolith. Fish lay down daily layers in their otoliths that are made up of elements from the water where a fish is currently living. These daily bands accrete into monthly and annual bands that fisheries biologist routinely use to age fish (Hubert et al. 1987; Figure 1). Because these bands accumulate daily over the lifetime of a fish, when it moves between isotopically different waters this signature is permanently recorded in the layers of the otolith (Muhlfeld et al. 2005, Barnett-Johnson et al. 2008).

The geomorphology surrounding Jackson Lake reflects a high degree of heterogeneity (Figure 2). This heterogeneity is highly predictive of differences in the strontium isotope signature of tributaries that arise within them and fish that inhabit or use them seasonally. Using this approach, we propose to: 1) characterize the strontium isotope signature of Jackson Lake and its tributary streams, 2) characterize the strontium isotope singature of fish living in these waters, and 3) use this information to link adult cutthroat trout in Jackson Lake back to their natal origins, investigate spawning site fidelity, and identify important tributaries of Jackson Lake important for Snake River cutthroat trout reproduction and survival.
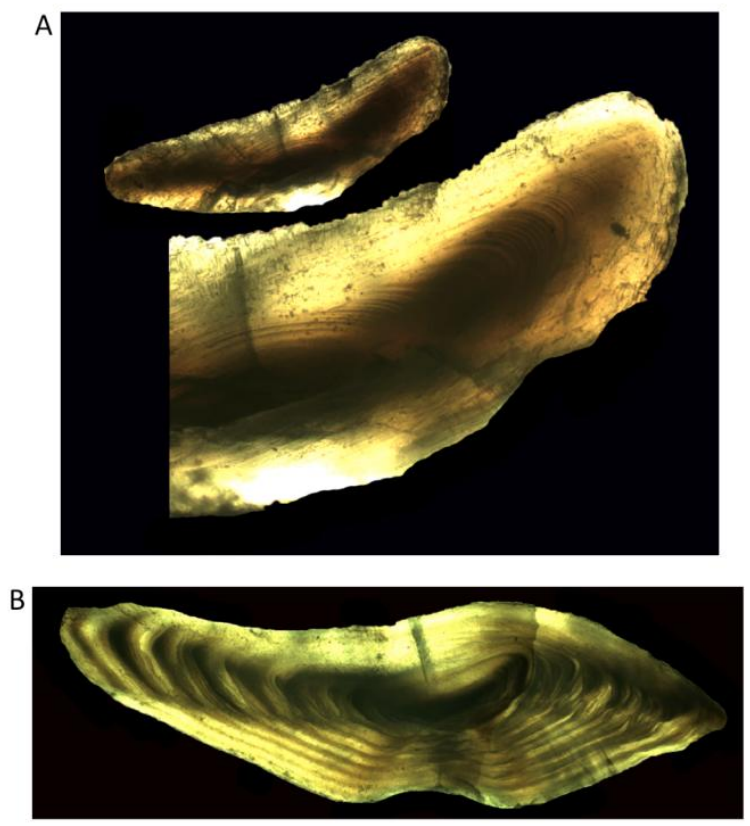

Figure1. Cross sections of otoliths reveal daily (A) growth bands, as seen in this hatch year fish and annual bands (B, alternating dark and light) we can use to age and extract life history movement information using strontium isotopes.

\section{$\uparrow \quad$ METHODS}

\section{Water Sampling and Analysis}

During low flow conditions in mid to late August we sampled water from upper, middle and lower Jackson Lake. Additionally, we sampled tributaries above their confluence with Jackson Lake and when necessary above and below confluences of tributaries prior to their merging and entering Jackson 
Lake. Sampling during low periods provides a strontium isotope characterization that is more reflective of the annual water chemistry that would be experienced by cutthroat trout in Jackson Lake and its tributaries during the largest period of the year (i.e. distinguished from pulsed from Spring runoff). Samples were analyzed for their strontium isotope composition at the Interdisciplinary Center for Inductively Coupled Plasma Mass Spectrometry at the University of California, Davis.

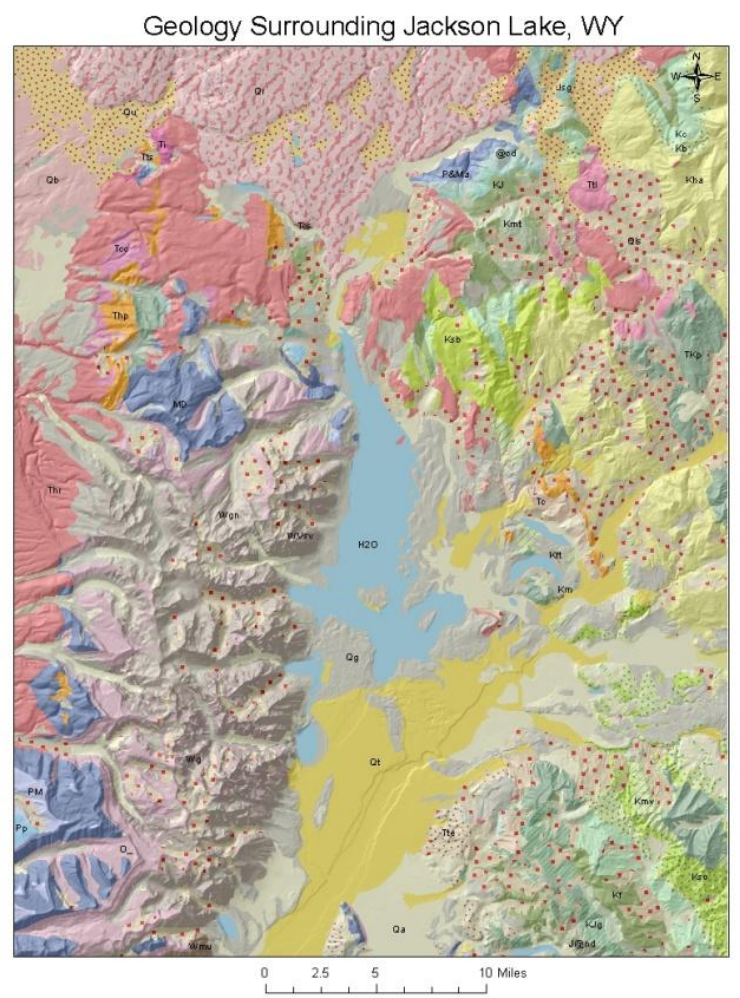

Figure 2. The geology surrounding Jackson Lake is highly variable. With Granites dominating along the western shore, volcanic in the north, and sandstones/limestones in along the eastern and southern shores. We can use this variation to differentiate trout that reside in streams within each of these geologic formations.

\section{Fish Sampling and Otolith Analysis}

Concurrent with water sampling, we collected five cutthroat trout from tributary streams of Jackson Lake using standard hook and line techniques and backpack electrofishing in cooperation with Park Service fisheries biologists and technicians during August, 2011. Our sampling efforts were guided and prioritized using a Wyoming Game and Fish Department administrative report detailing the distribution and occurrence of salmonid species in the upper Snake River basin; which includes Jackson Lake and its tributaries (Stephens 2008; Figure 3).

In cooperation with the Wyoming Game and Fish Department in Jackson, Wyoming, we also collected cutthroat trout and lake trout during annual Jackson Lake sampling work at the end of June, 2011 to obtain otoliths for isotope analysis. Lake trout were collected to characterize the isotopic signature of fish originating in Jackson Lake. Otoliths were cross-sectioned at the University of Wyoming using an Isomet $^{\circledR}$ low speed bone saw. Sections were mounted on chem slides and strontium isotope analysis was performed at the Interdisciplinary Center for Inductively Coupled Plasma Mass Spectrometry at the University of California, Davis.

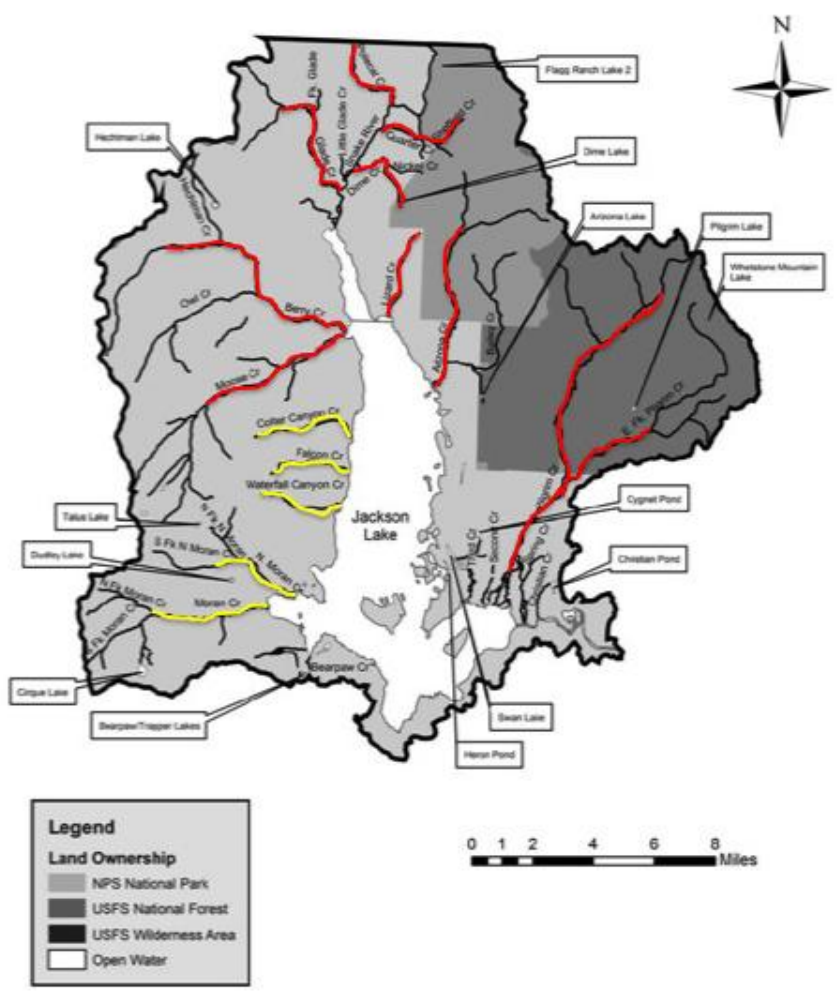

Figure 3. Map of Jackson Lake and associated watershed showing locations where we collected fish and water samples (red lines) and locations where only water samples were collected (yellow lines). Reprinted with permission from Wyoming Game and Fish Department (Stephens 2008).

\section{Statistical Analysis}

We used discriminant function analysis to determine how well strontium stable isotopes correctly classified trout from known collection sites. 


\section{Preliminary RESUlts}

Water samples and otoliths collected at the same location produced similar strontium isotopic signatures (Table 1). Initial discriminant function analysis was able to correctly classify $64 \%$ of fish to the correct tributary of origin (Table 2). After grouping Pilgrim, Dime, and Sheffield Creeks, the correct classification increased to $84 \%$ (Table 3).

Table 1. Strontium isotope values reveal a tight relationship between otoliths and water sampled at collections sites.

$$
\text { Otolith Water }
$$

$\begin{array}{ccccc}\text { Location } & \text { Sr87/Sr86 } & \text { SE } & \text { Sr87/Sr86 } & \text { SE } \\ \begin{array}{c}\text { Pilgrim } \\ \text { Creek }\end{array} & 0.7102 & 0.00002 & 0.7103 & 0.000006 \\ \begin{array}{c}\text { Arizona } \\ \text { Creek }\end{array} & 0.7099 & 0.00003 & 0.7092 & 0.000004 \\ \begin{array}{c}\text { Lizard } \\ \text { Creek }\end{array} & 0.7102 & 0.00001 & 0.7093 & 0.000006 \\ \begin{array}{c}\text { Dime } \\ \text { Creek }\end{array} & 0.7102 & 0.00021 & 0.7103 & 0.000005 \\ \begin{array}{c}\text { Sheffield } \\ \text { Creek }\end{array} & 0.7102 & 0.00005 & 0.7097 & 0.000004 \\ \begin{array}{c}\text { Polecat } \\ \text { Creek }\end{array} & 0.7102 & 0.0006 & 0.7120 & 0.000005 \\ \begin{array}{c}\text { Glade } \\ \text { Creek }\end{array} & 0.7102 & 0.00003 & 0.7094 & 0.000006 \\ \text { Berry } & 0.7102 & 0.00009 & 0.7127 & 0.000004 \\ \text { Creek } & 0.7102 & - & 0.7152 & 0.000004 \\ \begin{array}{c}\text { Moose } \\ \text { Creek }\end{array} & 0.7100 & 0.00002 & 0.7100 & 0.000005 \\ \text { Jackson } \\ \text { Lake } & & & & \end{array}$

\section{$\downarrow$ MANAGEMENT IMPLICATIONS}

In the Jackson Lake watershed, the ability to identify and prioritize important streams utilized for spawning and as juvenile rearing habitat for cutthroat trout was identified as a priority research need by biologists within the Greater Teton National Park. Using strontium stable isotope analysis in the Jackson Lake watershed we were able to: 1) determine that fish isotopically resembled their stream of origin and 2) that we could uniquely identify streams and mainstem bodies of water, Snake River/Jackson Lake, from each other. Understanding which tributary streams contribute to juvenile recruitment and, if possible, whether or not this contribution is evenly distributed throughout the watershed is important for prioritizing the expenditure of time, manpower, and money to protect and conserve streams important to growth and survival of juvenile cutthroat trout. Data from this study builds the foundation that future studies can build upon so that: 1) natal origins and spawning site fidelity may be determined for adult cutthroat trout in Jackson Lake and the lower Snake River, 2) characteristics of these streams that make them ideal for juvenile recruitment can be measured and compared across the watershed, and 3) results from this and future studies can inform sound, science-based management decisions.

Table 2. Results of discriminant function analysis reveal that Pilgrim, Dime, and Sheffield Creeks are difficult to distinguish isotopically from each other. Rows represent assignment to stream of origin based on isotopic signature (e.g. Glade Creek correctly placed all five samples as originating in Glade Creek whereas Pilgrim Creek assigned three of its individuals to Pilgrim Creek and as originating in Sheffield).

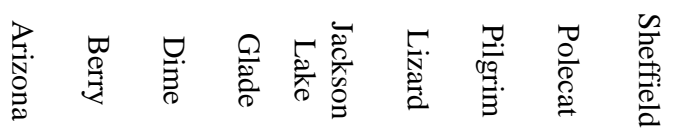

$\begin{array}{llllllllll}\text { Arizona } & \mathbf{4} & 0 & 0 & 0 & \mathbf{1} & 0 & 0 & 0 & 0 \\ \text { Berry } & 0 & \mathbf{4} & 0 & 0 & 0 & 0 & \mathbf{1} & 0 & 0 \\ \text { Dime } & 1 & 0 & 0 & 0 & 0 & 0 & \mathbf{4} & 0 & 0 \\ \text { Glade } & 0 & 0 & 0 & \mathbf{5} & 0 & 0 & 0 & 0 & 0 \\ \text { Jackson } & \mathbf{1} & 0 & 0 & 0 & \mathbf{8} & 0 & 0 & 0 & \mathbf{1} \\ \text { Lake } & & 0 & 0 & 0 & 0 & \mathbf{5} & 0 & 0 & 0 \\ \text { Lizard } & 0 & 0 & 0 & 0 & 0 & 0 & \mathbf{3} & 0 & \mathbf{2} \\ \text { Pilgrim } & 0 & 0 & 0 & 0 & 0 & 0 \\ \text { Polecat } & 0 & 0 & 0 & 0 & 0 & 0 & \mathbf{2} & \mathbf{3} & 0 \\ \text { Sheffield } & 0 & 0 & 0 & 0 & \mathbf{1} & 0 & \mathbf{4} & 0 & 0\end{array}$

Table 3. Results of discriminant function analysis after combining Pilgrim, Dime and Sheffield Creeks (Combined) increased correct classification of origin from $64 \%$ to $84 \%$.

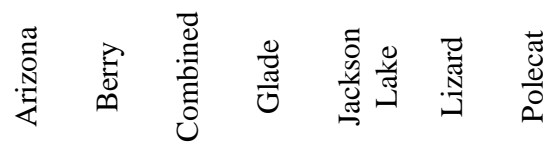

$\begin{array}{lccccccc}\text { Arizona } & \mathbf{4} & 0 & 0 & 0 & \mathbf{1} & 0 & 0 \\ \text { Berry } & 0 & \mathbf{4} & 1 & 0 & 0 & 0 & 0 \\ \text { Combined } & 1 & 0 & 13 & 0 & 1 & 0 & 0 \\ \text { Glade } & 0 & 0 & 0 & \mathbf{5} & 0 & 0 & 0 \\ \text { Jackson } & \mathbf{1} & 0 & 1 & 0 & \mathbf{8} & 0 & 0 \\ \text { Lake } & 0 & 0 & 0 & 0 & 0 & \mathbf{5} & 0 \\ \text { Lizard } & 0 & 0 & 2 & 0 & 0 & 0 & \mathbf{3} \\ \text { Polecat } & 0 & & & & & & \end{array}$


Although a more thorough discussion of our preliminary results would at this point be premature, we expect that our analyses over the coming years will offer new insights to managers making conservation decisions for Snake River cutthroat trout.

\section{$\downarrow \quad$ FUTURE DIRECTIONS}

This short study has provided the baseline data showing that we can differentiate tributaries and fish across the watershed. It is important to note that this study represents a small sample size from each location and water samples represent a snapshot of the isotopic value of the water. Future studies should build upon our results by: 1) increasing sample sizes of fish from each tributary, 2) sample adult cutthroat trout from Jackson Lake, 3) sample water at different locations from the top to the bottom of tributary streams, 4) include trace element profiles with isotope analysis to increase our ability to differentiate tributaries, and 5) investigate the use of non-invasive sampling techniques by comparing otolith and scale isotope values.

\section{ACKNOWLEDGEMENTS}

This project was supported by a grant from the UW-NPS Research Station. Field work was supported by Dianne Miller (WYGFD), Clark Johnson, Seth Newsome, and Hank Harlow. Technical assistance was provided by Rob Gipson and Tracy Stephens with the Wyoming Game and Fish Department and Shawn Lanning with the Wyoming GIS Center at the University of Wyoming.

\section{$\uparrow \quad$ LiTERATURE CiTED}

Baker G, Darby N, Williams N, Wullschleger J. 2008. Bonneville cutthroat trout restoration project great Basin National Park. Natural Resource Report NPS/NRPC/Nrr-2008/055.

Barnett-Johnson, R, Pearson TE, Ramos FC, Grimes CB, MacFarlane RB. 2008. Tracking natal origins of salmon using isotopes, otoliths, and landscape geology. Limnology and Oceanography. 53:1633-1642.

Behnke RJ. 1992. Native trout of western North America. American Fisheries Society, Monograph 6, Bethesda, MD.
Coghlan, SM, Lyerly MS, Bly TR, Williams JS, Bowman D, Hannigan R. 2007. Otolith chemistry discriminates among hatcheryreared and tributary spawned salmonines in a tailwater system. North American Journal of Fisheries Management. 27:531-541.

Hitt NP, CA Frisselll, CC Muhlfeld, Allendorf FW. 2003. Spread of hybridization between native westslope cutthroat trout, Oncorhynchus clarki lewisi, and non-native rainbow trout, Oncorhynchus mykiss. Canadian Journal of Fisheries and Aquatic Sciences. 60:11440-1451.

Hubert WA, Baxter GT, Harrington M. 1987. Comparison of age determinations based on scales, otoliths, and fin rays for cutthroat trout from Yellowstone Lake. Northwest Science. 61:32-36.

Kershner J. 1995. Bonneville cutthroat trout. In: Young MK, editor. Conservation assessment for inland cutthroat trout. General Technical Report RM-256. U.S. Forest Service, Rocky Mountain Forest and Range Experiment Station. Fort Collins, CO.

Liknes GA, Graham PJ. 1988. Westslope cutthroat trout in Montana: life history, status, and management. In: Gresswell RE, editor. Status and management of interior stocks of cutthroat trout. American Fisheries Society, Symposium 4, Bethesda, MD. pp. 53-60m

Muhlfeld CC, Marotz B, Thorrold SR, Fitzgerald JL. 2005. Geochemical signatures in scales record stream of origin in westslope cutthroat trout. Transactions of the American Fisheries Society. 134:949-959.

Stephens T. 2008. Survey of the Upper Snake River Basin upstream of the Pacific Creek confluence Wyoming. Wyoming Game and Fish Department fish division administrative report.

USDA Forest Service. 1996. Conservation assessment for inland cutthroat trout: Distribution, status, and habitat management implications. USFS Intermountain Region, Ogden, Utah.

Walther BD, Thorrold SR, Olney JE. 2008. Geochemical signatures in otoliths record natal origins of American shad. 
Transactions of the American Fisheries Society. 137:57-69.

Young MK, Harig AL. 2002. Critique of the recovery of greenback cutthroat trout. Conservation Biology. 15:1575-1584.
Ziegler JM, Whitledge GW. 2010. Assessment of otolith chemistry for identifying source environment of fishes in the lower Illinois River, Illinois. Hydrobiologia. 638. 